\title{
Research On The Value Of AACSB Business Accreditation In Selected Areas: A Review And Synthesis
}

Steven C. Hunt, Western Illinois University, USA

\begin{abstract}
The AACSB claims that its accreditation provides evidence of business school quality in a variety of areas. This paper reviews and synthesizes existing research on the value of AACSB accreditation on four key topics of importance to schools, prospective students, and employers: effect on obtaining quality students, students' job placement, faculty recruitment, and teaching quality. The very limited research comparing AACSB to other business accreditation is also examined. Overall, the analysis indicates very mixed support, at best, for the claims of AACSB schools' superiority in these areas. This analysis should be useful for business schools, employers, and prospective business students.
\end{abstract}

Keywords: Accreditation; AACSB; Business School Quality

\section{INTRODUCTION}

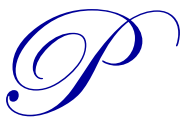

rospective business students and firms that hire business students for internships or entry-level positions must make difficult choices about schools to attend or at which to recruit. One possible classifying factor for both decisions is accreditation. The Council for Higher Education Accreditation (CHEA) defines accreditation as "a process of external quality review created and used by higher education to scrutinize colleges, universities and programs for quality assurance and quality improvement" (Eaton, 2012, p. 1). Such accreditation is believed by many colleges and universities to be valuable in improving their "brand," and thus enabling them to better attract students and to help in placement upon graduation. As many public schools face decreasing state support, tuition becomes an increasing portion of the school's revenue, thus attracting students becomes more urgent.

This paper has two purposes. One is to discuss the three major business accreditation organizations and how they have evolved in recent years. A second objective is to review, summarize, and integrate research on accreditation effects in several areas that would be expected to be of most interest to students and employers: student quality, career success, faculty hiring, and faculty teaching effectiveness. A key reason for this approach is to evaluate the validity of claims made by the Association to Advance Collegiate Schools of Business (AACSB) about the value of its accreditation in these areas. This analysis should be valuable to schools considering accreditation, accredited schools looking to market their accreditation, employers of business school graduates, and business students.

The next section discusses the three major accrediting bodies and differences and similarities among them. A subsequent section contains discussion of the results of research involving the four alleged benefits of accreditation stated above. Most of the research to date has focused on the AACSB, but the limited research on other accrediting bodies is also discussed. Finally conclusions are offered. 


\section{BUSINESS SCHOOL ACCREDITING ORGANIZATIONS AND THEIR DEVELOPMENT}

There are three major organizations accrediting US business programs. There are also regional accrediting bodies, such as North Central, which accredit an entire university as opposed to a program or set of programs. In the latter case, there may be substantial variations in the quality of individual departments or programs.

The oldest, best-known and most respected (White et al., 2008; Lindsay \& Campbell, 2003; Jantzen, 2000) business school accreditor is the AACSB. Currently 694 business schools in almost 50 countries are accredited by the AACSB. The AACSB also offers separate accounting program accreditation. The well-known accounting honor society, Beta Alpha Psi, may only be found at AACSB-accredited institutions.

The AACSB views its value as having accredited schools constantly focus on their mission and then develop a strategic management plan to use their human, financial, and physical resources to achieve their goals. A systematic assessment then must be done to determine if these goals are being met. Continuous improvement of the business program is an important part of the process. Accredited schools perform a detailed assessment of student learning to focus on ways to improve their curricula. In April, 2013, the AACSB approved new standards that focused on innovation in business schools, a requirement of demonstrated impact of research, increased focus on ethics in the business curriculum, and requiring considerable engagement among faculty, students, and businesses.

Before the mid-1990s AACSB schools tended to be large and research oriented. One reason for this was that obtaining and retaining AACSB accreditation was a time-consuming and costly enterprise involving the hiring of sufficient highly-paid doctorally-qualified faculty (often with reduced teaching loads). Therefore such accreditation might have been considered infeasible for some schools, such as regional comprehensive state schools and liberal arts colleges focusing on instruction rather than research.

A competing business accreditation body, the Association of Collegiate Business Schools and Programs (ACBSP), later renamed the Accreditation Council for Business Schools and Programs, was founded in 1988 to appeal to smaller, teaching-oriented schools which had difficulty meeting the accreditation requirements of the AACSB. The new organization still had a largely prescriptive, input-based approach. Many standards were similar to those of the AACSB but were more teaching-oriented and less toward generating new knowledge. Unlike the AACSB, the ACBSP also accredits two-year programs, which make up almost half of schools accredited by ACBSP. ACBSP also accredits liberal arts colleges with small business programs and non-traditional universities such as the University of Phoenix. Scholarly requirements for faculty at such institutions may be limited. There are currently 800 schools accredited by the ACBSP, most of them in the US. The ACBSP also began providing separate accounting program accreditation in 2010 (ACBSP, 2013).

To meet a perceived threat from the ACBSP, in 1994 the AACSB adopted a mission-based approach, under which primarily teaching institutions would be able to set their goals and demonstrate their achievement with less research emphasis. Mission driven standards thus were more flexible than a single set of standards applying to all schools. In 2003 the AACSB developed assurance of learning, under which each school sets its own learning goals suitable to the characteristics, circumstances, and mission of the school. Such changes enabled the better-known AACSB to continue expanding its list of accredited schools even in the face of competition from the ACBSP. From 1919-1988, 260 business schools earned accreditation; in the last 25 years that number has increased $160 \%$. As more and more schools became accredited, it became more difficult to view such accreditation as a sign of excellence. The Dean at Georgetown University's School of Business, David Thomas, stated, "The presence of accreditation doesn't differentiate you [as an elite school], but the absence of it does cause more noise and questions." NonAACSB schools now may worry that they will be viewed negatively by the public (Corcoran, 2006). So the AACSB's growth continues.

After greatly increasing the number of accredited programs in the US, the AACSB is looking overseas for much of its future growth. In the 24 months ending January 2014, 51 new schools were accredited. Only twelve of these were US schools (eight offered only undergraduate degrees in accounting, three also offered MBAs and one offered a master's degree in accounting (Hasselback, 2013)). 
In 1998 a third organization was created. The International Assembly of Collegiate Business Education (IACBE) claimed to be more flexible than the ACBSP. The IACBE focuses on outcomes assessment more than the other two. Input requirements (such as number of PhDs on the faculty) are lower. IACBE schools overwhelmingly reported the existence of nontraditional programs. The IACBE competes primarily with the ACBSP. The IACBE currently has 165 accredited schools, the great majority of which are in the US. Although accreditation principles of the IACBE generally appear similar to the standards of the ACBSP, they are seen as more flexible. This is because standards must be met, while principles are broader statements that "should" be met. The faculty qualification standards are considerably less stringent than those of the other accreditors in requirements for terminal degrees.

All three accreditations are similar with respect to mission-aligned accreditation processes. For all three the activities, modes of instruction, course offerings, research productivity, and facilities must line up with the stated strategic intent, as reflected in the mission statement (Julian \& Ofori-Dankwa, 2006). AACSB is known as the most rigorous.

Brink and Smith (2012) noted that of the three, AACSB schools had the most assets, most revenue overall and from other than tuition and fees, highest faculty salaries, and the most personnel and students. IACBE had the least assets, generated the least total core revenue, paid the lowest faculty salaries, and had the fewest personnel. ACBSP was between the AACSB and IACBE but much closer to the latter. So it appears as if a school's resources influence its choice of accreditor. This makes sense, since the direct cost of achieving and maintaining AACSB accreditation (such as application fees, conferences, and consultants' fees) has been estimated as at least three to four times that of the others. Higher faculty salaries that are typically found at AACSB-accredited schools (Hedrick et al., 2010 and Bell \& Joyce, 2011) are a major cost, as well.

AACSB accreditation's value may vary based on the type of school. Tullis and Camey (2007) note that smaller regional and private schools may benefit the most. AACSB accreditation has always been most important to such middle-tiered schools (White et al., 2008). Programs known nationally or internationally for the quality of the faculty, strict admissions standards, and excellent placement have strong reputation and name recognition and do not need accreditation. Middle-tiered schools have used AACSB accreditation as an effective way to differentiate themselves from lower-tiered schools while claiming to be similar to well-known and respected universities (White et al., 2008). Some schools take this to extremes. One low-rated school promoted its AACSB accreditation by misleadingly claiming that its business programs had been judged equal to those of Harvard and Stanford, among others.

Even though the AACSB approach is similar in many ways to the ACBSP and to some extent the IACBE, the AACSB strongly maintains a belief in the superiority and rigor of its approach. It has pushed hard to be viewed as the "gold standard for accreditation of all legitimate baccalaureate and graduate business programs" (Tullis \& Camey, 2007, p.47). The AACSB would like for various parties to consider a non-AACSB school that is accredited by another organization to be "a nonaccredited school and therefore not capable of providing a legitimate business degree" (Tullis \& Camey, 2007, p. 47).

\section{AACSB ASSERTIONS AND RESEARCH ON SELECTED ASPECTS OF BUSINESS PROGRAM ACCREDITATION}

The AACSB is not shy about advertising alleged benefits of its accreditation. Their website indicates that "AACSB-accredited schools have the highest quality faculty, relevant and challenging curriculum, and provide educational and career opportunities that are not found at other business schools." It further states, "AACSBaccredited schools produce graduates that are highly skilled and more desirable to employees than other nonaccredited schools" (AACSB, 2013). In their websites, the ACBSP and IACBE refer to advantages of accreditation per se but do not make claims about the value of their accreditation as opposed to others.

\section{Attracting Quality Students}

Many business deans think AACSB accreditation helps attract and graduate better students (Romero, 2008). Roberts et al. (2004) found that faculty perceived that AACSB accreditation was likely to lead to success in 
attracting top students. There is limited support for this perception. Kenderman (2009) quoted several college officials as indicating that specialized accreditation itself (AACSB or other accreditor) was not of great concern to students or their parents. A consulting firm report (Abrahamson, 2010) found that accreditation was not mentioned among factors that high-achieving high school seniors and their parents for selecting a particular school. One problem is that there are numerous accreditation bodies and customers are confused. Also, accrediting bodies offer membership status to nonaccredited schools. Students and employers may not understand that a member school has not necessarily achieved accreditation. On the other hand, Alexander and Hatfield (1995) found AACSB accreditation was a major reason for students to transfer to a new school.

The accredited status of business programs may be less important than the reputation of the institution in attracting students. However, AACSB accreditation may be a part of a school's reputation. Wolk (2007) noted that US News and World Reports and other rankings look at AACSB accreditation and not others. International students may be more concerned about AACSB accreditation because of a lack of other information about US schools (Kelderman, 2009).

AACSB accreditation may have a greater effect on attracting graduate students. Unlike undergraduates who often are recruited by the university itself, graduate business students are typically recruited directly by the business school (Trifts, 2012). In comparing two or more similar programs the AACSB accredited one may have an advantage. AACSB accreditation was found to be a significant factor for potential students when comparing online MBA programs (Rydzewski et al., 2010). Most AACSB accredited schools will not accept undergraduate business credits from non-AAACSB accredited schools for first year MBA core course requirements (Espiritu, 2007).

Several studies examined student quality. Lindsay and Campbell (2003) found some evidence that AACSB accredited schools attracted better students, based on ACT scores. Espiritu (2007) found that accredited schools had a $23 \%$ higher graduation rate and $15 \%$ higher full-time retention rate. Even after controlling for other factors of the institutions and their students, AACSB schools still had an advantage. Measures of student output quality were very limited. Roller et al. (2003) found that faculty at AACSB-accredited schools rated accreditation more important in ensuring the quality of student learning than did those at ACBSP or IACBE schools. However, accounting and economics faculty surveyed in Eschenfelder et al. (2014) reported their belief that AACSB accreditation had not improved student learning.

An indirect measure of student output quality is performance on professional examinations. Lindsay and Campbell (2003) found that AACSB accredited schools had higher CPA exam pass rates, even when taking into account the higher ACT scores of students at AACSB accredited schools. Howell and Heshizer (2008) found that AACSB accreditation was associated with passing the CPA in fewer attempts. Barilla et al. (2009) found that separate AACSB accounting accreditation, but not simply business accreditation, led to increased success rates of first time CPA candidates. ACBSP, but not IACBE, business accreditation led to greater success as well.

Another possible measure of student output quality was indicated by Hutchens and Olbrecht (2009), who found that graduates from AACSB-accredited programs were less likely to apply to graduate schools. Those who did so were less likely to be accepted. This was deemed to be likely due to their earning higher wages and thus having greater marginal costs to attend graduate school or that graduates from AACSB-accredited programs might apply to more selective graduate schools.

\section{Job Placement And Career Success}

Some support exists for the idea that recruiters view such accreditation favorably in making hiring decisions. Shipley and Johnson (1991) found that, for those employers familiar with the AACSB, that graduation from an AACSB-accredited program was a plus for a job applicant. However, many employers were unaware of the AACSB; as a result, only $36 \%$ of employers considered AACSB accreditation as a major consideration in evaluating a job candidate. Other studies, Roberts et al. (2004 and 2006), found that faculty believed that AACSB accreditation benefitted employers and thus was helpful to students in getting hired. Difficulties in assessing quality of new online accounting degrees may make AACSB accreditation for such programs particularly valuable. Kohlmeyer et al. 
(2011) found that employers were much more willing to hire an individual with an online accounting degree if the program had AACSB accreditation.

The average starting salary of graduates is useful in comparing business programs from different schools (Kreutzer and Wood, 2007). Research results are mixed as to whether graduates from AACSB accredited schools received higher starting salaries. Kim et al. (1996) and Olbrecht and Yeaton (2011) found higher starting salaries for graduates from AACSB-accredited schools. However, Kreutzer and Wood (2007) suggested that starting salaries were strongly positively related to SAT scores. Thus the higher starting salaries noted above may be due to higher SAT scores rather than having attended an AACSB accredited institution. Bastin and Kalist (2013) found no entrylevel wage premium related to graduating from an AACSB-accreditation after consideration of other factors such as SAT scores and GPA.

Does accreditation of one's school predict career success? This is an issue of considerable importance to employers and students. Olbrecht and Yeaton (2011) found a positive relationship between AACSB accreditation and salaries 10 years after accreditation. This effect was primarily among unranked schools. However, Jalbert et al. (2011) found compensation to be lower for CEOS who graduated from AACSB-accredited schools. Companies with CEOS without degrees from AACSB-accredited schools outperformed those with CEOS who had a degree from an AACSB-accredited school. However, the great majority of undergraduate and graduate degrees held by CEOs in the study were from AACSB-accredited schools. Such accreditation may have facilitated their hiring and career advancement.

\section{Hiring Quality Faculty}

Does accreditation help a school hire desirable faculty? Roberts et al. (2004) found that this was a perception of faculty at newly AACSB-accredited schools. Roller et al. (2003) reported that respondents (deans and chairs of business schools) from all groups (business programs accredited by AACSB, ABCSP, and IACBE) agreed that AACSB accreditation helps with faculty recruitment. Roberts et al. (2006) reported that faculty hired after a school achieved AACSB accreditation overwhelmingly indicated their preference for working at such an institution, as well as indicating that AACSB accreditation helped their school obtain appropriate faculty. Certainly in a time of shortage of new accounting professors and record numbers of accounting graduates, hiring faculty is critical. Accreditation itself may be of limited value in attracting faculty, as applicants are likely to select a position for other reasons (base salary, teaching load, research support, etc.). However, these should be higher in AACSB accredited schools.

\section{Teaching Quality}

There are conflicting reports as to whether accreditation improves teaching. The AACSB (2008) states that faculty who engage in research are more likely to be current in their teaching, implying that greater emphasis on research at AACSB-accredited schools should lead to improved teaching. However, there is little evidence to support that claim. Taylor and Stanton (2009) found that faculty in non-doctoral granting business schools believed that their research improved their teaching. However, respondents generally indicated that most of them did not use their research in preparing class materials and that publishing in top journals did not lead to higher quality teaching than publishing in other outlets. So it is unclear as to how research affected teaching quality. Lee and Quddus (2008) found that many faculty performed research in areas other than their teaching specialties. One reason for this was that many taught financial accounting at small schools that could not afford financial accounting databases such as COMPUSTAT and thus did research in non-financial areas. Thus they were not producing financial accounting research to use in the classroom. It is possible that some performed education research that might have aided in classroom performance.

Some feel that the greater research emphasis at AACSB accredited schools must reduce teaching quality by taking time away from classroom preparation and developing teaching innovations, as supported by perceptions of existing faculty at schools that had recently achieved AACSB accreditation (Roberts et al., 2004) and by respondents from non-AACSB accredited schools (Roller et al., 2003). However, new faculty hired after their schools obtained AACSB accreditation perceived themselves as highly valuing teaching (Roberts et al., 2006). 
Roller et al. (2003) found that deans and business school chairs considered their own school's accrediting body the best of the three for teaching excellence. Non-AACSB accredited schools were found to have higher teaching relevance and lower research productivity than AACSB-accredited schools (Iossifova, 2008). However, teaching relevance was measured only by student perceptions. Students may not be in a position to accurately evaluate the relevance of coursework until after beginning their careers. Lindsay and Campbell (2003) found that AACSB accreditation was not associated with low student/faculty ratios, which some consider useful for enhancing accounting education.

\section{CONCLUSIONS}

While accreditors may claim that accreditation implies excellence, some view it differently. Yunker (2000) noted that having accreditation is more like getting a diploma than having an excellent transcript. Having accreditation means that the school meets the minimum standards of the accrediting agency, but should not imply that the program is better than others.

Overall, the research discussed above does not provide consistent evidence of AACSB accredited schools' superiority over others. Several limitations of existing research make it difficult to determine quality differences among schools holding different accreditations or between AACSB accredited schools and those without accreditation by one of the other two groups. Much of the research deals with perceptions, since measurement in some important areas, such as teaching effectiveness, is difficult. However, perceptions are important since they may influence the behavior of various stakeholders, such as potential students and their employers.

It is also very difficult to determine the value of accreditation to various stakeholders. If AACSB accredited schools, on average, have greater resources than non-AACSB accredited schools, then they might be expected to use these resources to attract students and faculty. The accreditation status itself may be of less value to these groups than factors that might underlie a school's choice of accreditation.

As noted earlier, the AACSB has expanded rapidly in recent years. Having AACSB accreditation has become more common and has perhaps lost some of the distinction it once had. This may partially explain some of the differences in research results between newer studies (such as Abrahamson, 2010) and older ones in which the latter found advantages for AACSB accreditation and the former did not.

Limited research has examined accreditation other than AACSB. Most studies have lumped non-AACSB accredited schools into a "nonaccredited" category. This makes it difficult to use existing research to compare schools holding different accreditations.

It is unclear from the research whether the higher perceived status of the AACSB compared to other business accreditors represents quality differences in various areas or simply greater longevity and better marketing. Overall, results are limited in support of AACSB assertions that AACSB accreditation provides better education or job prospects to students or better entry-level job candidates to potential employers. Many non AACSB-accredited schools may hire faculty with greater and/or more recent work experience, which they may then use in their teaching. Further research is needed to identify actual quality differences between accredited and nonaccredited schools and among the different accreditations (Brink \& Smith, 2012).

It will be interesting to determine how the recent AACSB standards requiring determination of the impact of research will affect the perception of AACSB accreditation. Focusing research on practice-oriented issues related to the business school's mission should help improve the likelihood that it will positively impact faculty members' teaching. It is possible that more AACSB schools will then have both high research productivity and teaching relevance than found in Iossifova (2008).

The above research is limited to four potential benefits of accreditation. This paper does not discuss research into all possible benefits of accreditation nor does it delve into an examination of the costs of obtaining and maintaining accreditation. In terms of other benefits, for example, pursuing and achieving accreditation has caused some schools to examine their programs carefully and make necessary improvements. Being able to share 
techniques and challenges of doing so with similar member schools is also valuable (Roller at al., 2003). Administrators have reported increased funding from the school as a result of accreditation (Trifts, 2012). However, schools certainly can work to improve their programs on their own, and may be able to obtain school resources to do so. Those schools that believe that they are providing a quality academic experience for their students and that those students are in demand by desirable employers may not need the approval of the AACSB or, for that matter, other accreditors.

\section{AUTHOR INFORMATION}

Steven C. Hunt is an associate professor of accounting at Western Illinois University. He has published in a number of journals, including the Journal of Accounting Literature, Issues in Accounting Education, Journal of Accounting Education, and Accounting Forum. He received his $\mathrm{PhD}$ from the University of Florida and bachelors and masters degrees from the University of Georgia. Email: sc-hunt@ wiu.edu.

\section{REFERENCES}

1. $\quad$ AACSB. 2008. Impact of research report.

2. AACSB 2013. Retrieved from: http://www.aacsb.edu/aacsb-accedited/.

3. Abrahamson, T. 2010. How high-achieving seniors choose their college: The four new rules. Higher Education Marketing Report, 24(8), 1-2.

4. ACBSP. 2013. ACBSP grants accreditation to 25 colleges and universities in nine countries. Retrieved from www.acbsp.org/news/news.asp?id=149,500.

5. Alexander, R.P. \& Hatfield, D. 1995. Does AACSB accreditation impact enrollment? The Coastal BusinessJournal, 1(1), 47-52.

6. Barilla, A.G., Jackson, R.E., \& Mooney, J.L. 2008. The CPA exam as a postcurriculum accreditation assessment. Journal of Education for Business, 83(5), 270-274.

7. Bastin, H., \& Kalist, D.E. 2013. The labor market returns to AACSB accreditation. Journal of Labor Research, 34(2), 170-179.

8. Bell, R.L., \& Joyce, M.P. 2011. Comparing business faculty's salaries by rank and gender: Does AACSB accreditation really make a difference? Academy of Educational Leadership Journal, 15(2), 19-40.

9. Brink, K.E., \& Smith, C.E. 2012. A comparison of AACSB, ACBSP, and IACBE accredited U.S. business programs: An institutional resource perspective. Business Education and Accreditation, 4(2), 1-15.

10. Corcoran, C. 2006. AACSB accredited business programs: Differences and similarities. Journal of Business and Economics Research, 4(8), 41-48.

11. Eaton, J.S. 2012. An overview of higher education. CHEA. Retrieved from www.chea.org/pdf/overview of US accreditation 2012.pdf

12. Eschenfelder, M.J., Bryan, L.D., \& Lee, T.M. 2014. Motivations, costs, and results of AOL: Perceptions ofaccounting and economics faculty. Journal of Case Studies in Accreditation and Assessment 3, 1-14.

13. Espiritu, A. 2007. Is there a dividend to an institution for having an accredited college of business? Journal of American Academy of Business, Cambridge, 11(1), 269-274.

14. Hasselback, J. 2013. Accounting directory 2012-2013. Pearson Upper Saddle River, NJ.

15. Hedrick, D.W., Henson, S.E., Krieg, J.M., \& Wassell, Jr., C.S. 2010. The effects of AACSB accreditation on faculty salaries and productivity. Journal of Education for Business, 85(5), 284-291.

16. Howell,C., \& Heshizer, B. 2008. Characteristics that assist future public accountants pass the CPA exam on fewer attempts. Journal of Applied Business and Economics, 8(3), 57-66.

17. Hutchins, T., \& Olbrecht, A. 2009. The link between AACSB accreditation and graduate schools. American Journal of Business Education, 2(6), 89-96.

18. Iossifova, A. 2008. Research productivity, teaching relevance, and AACSB accreditation. The Quality Management Journal, 15(4), 46-56.

19. Jalbert, T., Jalbert, M., \& Furumo, K. 2011. Does AACSB accreditation matter? Evidence from large firm CFOs. Journal of Applied Business Research, 27(3), 93-105.

20. Jantzen, R.H. 2000. ACSB mission-linked standards: Effects on the accreditation process. Journal of Education for Business, 75(6), 343-348. 
21. Julian, S.D., \& Ofori-Dankwa, J.C. 2006. Is accreditation good for the strategic decision making of traditional business schools? Academy of Management Learning and Education, 5(2), 225-233.

22. Kelderman, E. 2009. Struggling colleges question the cost - and worth - of specialized accreditation. The Chronicle of Higher Education. Oct. 5.

23. Kim, K., Rhim, J., Henderson, W., Bizal, N., \& Pittman, G. 1996. AACSB accreditation: A positive signal in accounting job markets. Mid-Atlantic Journal of Business, 32, 123-134.

24. Kohlmeyer, J.M. III, Seese, L.P., \& Sincich, T. 2011. Online versus traditional accounting degrees: Perceptions of public accounting professionals. Advances in Accounting Education: Teaching and Curriculum Innovations, 12,139-165.

25. Kreutzer, D.W., and Wood, C. 2007. Value-added adjustments in undergraduate business school ranking. Journal of Education for Business, 82(6), 357-360.

26. Lee, B.B., \& Quddus, M. 2008. AACSB standards and accounting faculty's intellectual contributions. 23.Journal of Education for Business, 83(3), 173-179.

27. Lindsay, D.H., \& Campbell, A. 2003. An examination of AACSB accreditation status as an accounting program quality indicator. Journal of Business and Management, 9, 125-136.

28. Olbrecht, A., \& Yeaton, K. 2011. The value of undergraduate AACSB accreditation on the earnings of college graduates. Working paper. Ramapo College of New Jersey.

29. Roberts, W.A., Jr,, Johnson, R. \& Groesbeck, J. 2004. The faculty perspective on the impact of AACSB accreditation. Academy of Educational Leadership Journal, 8(1), 111-125.

30. Roberts, W.A., Jr., Johnson, R., \& Groesbeck, J. 2006. The perspective of faculty hired after AACSB accreditation on accreditation's impact and importance. Academy of Educational Leadership Journal, 10(3), 59-71.

31.. $\quad$ Roller, R.H., Andrews, B.K., \& Bovee, S.L. 2003. Specialized accreditation of business schools: A comparison of alternative costs, benefits, and motivations. Journal of Education for Business, 78(4), 197 204.

32. Romero, E.J. 2008. AACSB accreditation: Addressing faculty concerns. Academy of Management Learning and Education, 7(2), 245-255.

33. Rydzewski, D.N., Eastman, J.K., \& Bocchi, J. 2010. Important characteristics of an MBA program: Perceptions of online MBA students. American Journal of Business Education, 3(4), 33-41..

34. Shipley, M.F. \& Johnson, M. 1991. Employment and academic opportunities for graduates of AACSBaccredited schools. Journal of Education for Business, 66(4), 235-239.

35. Taylor, R.L., \& Stanton, A.D. 2009. Academic publishing and teaching effectiveness: An attitudinal study of AACSB accredited business school faculty. Academy of Educatonal Leadership Journal, 13(2) 93-106.

36. Trifts, J.W. 2012. The direct and indirect benefits and costs of AACSB accreditation. SAM Advanced Management Journal, 77(1), 20-27.

37. Tullis, K.J., \& Camey, J.P. 2007. Strategic implications of specialized business school accreditation: End of the line for some business education programs? Journal of Education for Business, 83(1), 45-51.

38. White, J.B., Miles, M.P., \& Levernier, W. 2008. AACSB International and the management of its brand: implications for the future. Journal of Management Development, 28(5), 407-413.

39. Wolk, R.M. 2007. Survival matters: Business schools, ubiquitous technology, and accreditation. Unpublished DBA dissertation. Nova Southeastern University.

40. Yunker, J.A. 2000. Doing things the hard way: Problems with mission-linked AACSB accreditation standards and suggestions for improvement. Journal of Education for Business, 75(6), 348-354. 